\title{
PEMBERDAYAAN MASYARAKAT DESA RENON MELALUI PEMBUATAN HAND SANITIZER ORGANIK DI TENGAH PANDEMI COVID-19
}

\author{
Maria Yunita Apriyati \\ Fakultas Ekonomi dan Bisnis Manajemen \\ Universitas Pendidikan Nasional Denpasar \\ Corresponding Author email: yhunaapriyati@gmail.com
}

\begin{abstract}
Antiseptics are substances that can inhibit the growth and development of pathogenic microorganisms such as viruses, bacteria, parasites, and fungi. aloe vera is a functional plant that is widely cultivated in Indonesia. Research shows aloe vera contains saponins, flavonoids, polyphenols, and tannins which are antiseptic. By utilizing aloe vera in Renon village, especially on Jalan Tukad Badung 18, Bali, South Denpasar, it can help local communities to maintain or develop the family economy during this pandemic. By introducing innovative and creative antiseptic products or hand sanitizers and the addition of aloe vera and lime juice, this product can make this product a way of dealing with viruses and bacteria in the midst of the Covid-19 virus in Indonesia so that people can maintain a healthy lifestyle.One of the goals is to make innovative products that are good for health and open employment opportunities for students and the general public. Hand sanitizers made of aloe vera are effective at killing germs and are also very efficient and economical during the Covid-19 pandemic.
\end{abstract}

Keywords:Antiseptic,covid-19, innovative

\begin{abstract}
Abstrak
Antiseptik adalah zat yang dapat menghambat pertumbuhan dan perkembangan mikroorganisme patogen seperti virus, bakteri, parasit, dan jamur. Lidah buaya (Aloe vera) merupakan tanaman fungsional yang banyak dibudidayakan di Indonesia. Penelitian menunjukkan lidah buaya (Aloe vera) memiliki kandungan saponin, flavonoid, polifenol, serta tanin yang bersifat antiseptik. Dengan memanfaatkan lidah buaya yang ada di kelurahan Renon, khususnya di jalan Tukad Badung 18,Bali Denpasar Selatan ini dapat membantu masyarakat setempat untuk mempertahankan atau mengembangkan ekonomi keluarga di masa pandemi ini. Dengan memperkenalkan produk antiseptik atau hand sanitizer yang inovatif dan kreatif serta penambahan lidah buaya dan perasan jeruk nipis dapat membuat produk ini menjadi salah satu cara penanganan diri terhadap virus dan bakteri di tengah maraknya virus Covid-19 di Indonesia agar masyarakat dapat menjaga pola hidup yang sehat. Salah satu tujuannya adalah membuat produk inovatif yang baik untuk kesehatan serta membuka lapangan pekerja untuk mahasiswa dan juga masyarakat umum.Hand sanitizer yang terbuat dari aloe vera ini efektif membunuh kuman dan juga sangat efisien serta ekonomis di masa pandemi Covid-19.
\end{abstract}

Kata kunci : Antiseptik,covid-19, inovatif.

@2021 Penerbit PS2PM FISIPKUM UNSERA

Segala bentuk plagiarisme dan penyalahgunaan hak kekayaan intelektual akibat diterbitkannya artikel pengabdian masyarakat ini sepenuhnya menjadi tanggung jawab penulis

Mari Yunita Apriyati, Pemberdayaan Masyarakat Desa Renon Melalui Pembuatan Hand Sanitizer Organik di Tengah Pandemi Covid-19 


\section{PENDAHULUAN}

Virus menular dengan mudah salah satunya melalui tangan. Oleh karena itu sering mencuci tangan adalah suatu keharusan untuk menghilangkan kuman penyebab penyakit yang ditularkan melalui kontak yang sering dengan orang lain.Hand sanitizer yang merupakan antiseptik pembersih tangan hadir sebagai jalan keluar dari permasalahan tersebut. Namun beberapa jenis gel antiseptik pembersih tangan (hand sanitizer) di pasaran masih menggunakan alkohol dengan konsentrasi $\pm 50 \%$ sampai $70 \%$ sebagai bahan antibakterinya. Begitu juga dengan kondisi sekarang ini dimana harga pasaran hand sanitizer sangat melambung jauh dari harga sebelum adanya virus ini.Penggunaan alkohol dalam pembersih tangan dirasa kurang aman terhadap kesehatan karena alkohol merupakan pelarut organik yang dapat melarutkan lapisan lemak dan sebum pada kulit yang berfungsi sebagai pelindung terhadap infeksi mikroorganisme. Alkohol juga mudah terbakar dan pada pemakaian berulang menyebabkan kekeringan dan iritasi pada kulit. Inilah kenapa hand sanitizer yang berasal dari bahan alam lebih aman digunakan, tidak mengandung zat kimia berbahaya, tidak merusak pernafasan, dan aman untuk anak-anak. Lidah buaya (Aloe vera) merupakan tanaman yang fungsional karena semua bagian dari tanaman ini dapat dimanfaatkan baik untuk perawatan tubuh maupun untuk mengobati berbagai penyakit. Berdasarkan hasil penelitian dilaporkan bahwa lidah buaya (Aloe vera) ini pun memiliki kandungan saponin, flavonoid, polifenol, serta tanin yang mempunyai kemampuan untuk membersihkan dan bersifat antiseptik.Dengan memanfaatkan lidah buaya yang ada di kelurahan Renon, khususnya di jalan Tukad Badung 18,Bali Denpasar Selatan ini 
dapat membantu masyarakat setempat untuk mempertahankan/ mengembangkan ekonomi keluarga di masa pandemi ini.Pembuatan hand sanitizer organik ini diawali dengan penyuluhan tentang manfaat dan kandungan lidah buaya dan juga jeruk nipis. Hal ini bertujuan agar masyarakat dapat mengetahui betapa banyak manfaat menggunakan hand sanitizer alami ini. Di Kondisi seperti sekarang ini sebagian orang kehilangan pekerjaan mereka dan tentu itu terjadi juga pada beberapa masyarakat daerah Renon.

Bahkan ada yang masih bekerja tetapi pendapatan yang didapatkan tidaklah sebanyak sebelum virus ini muncul.Masyarakat sebagian bekerja sebagai petani dan kuli bangunan. Sebagian besar penduduk belum bisa memanfaatkan hp sebagai media untuk mengakses informasi,terutama para orang tua. Dari fenomena tersebut terlihat bahwa kesadaran masyarakat terhadap penggunaan antiseptik sangatlah kurang.Padahal hand sanitizer ini sangat dibutuhkan di kondisi seperti ini, tetapi disisi lain berkurangnya pendapatan serta kurangnya kesadaran masyarakat akan pentingnya hand sanitizer untuk dibawa kemana-mana.Inilah kenapa saya mengangkat kasus ini sebagai judul proposal KKN. Seperti yang diketahui bahwa dampak kepanikan terhadap Covid-19 yang menjadi pemicunya adalah pemborongan hand sanitizer dan masker. Pemilihan pelepah lidah buaya sebagai bahan utama pembuatan hand sanitizer adalah karena lidah buaya sendiri bisa dengan mudah didapatkan di lingkungan tempat berlangsungnya kegiatan,dan juga lidah buaya memiliki kandungan yang sangat baik untuk kulit. Pembuatan hand sanitizer organik dari lidah buaya ini mengacu pada resep yang dikembangkan oleh dr.Rishi Desai,MD,MPH. Sejak berlangsungnya kegiatan ini masyarakat di lingkungan sekitar 
merasa terbantu dan sering membawa

hand sanitizer organik ini kemanapun mereka pergi.

\section{METODE PELAKSANAAN}

Waktu dan tempat kegiatan dilaksanakan mulai Februari 2021 hingga Maret 2021 di kelurahan Renon,Tukad Badung 18,Bali,Denpasar Selatan. Upaya untuk menyelesaikan permasalahan yang dihadapi berupa pelatihan pembuatan hand sanitizer adalah sebagai berikut:

\section{- Materi tertulis}

Materi tertulis meliputi penjelasan rinci tentang cara definisi, fungsi serta ringkasan pembuatan hand sanitizer.

\section{- Metode praktek}

Dimana sebelum melakukan proses pembuatan hand sanitizer ini, terlebih dahulu dilakukan persiapan lidah buaya hingga dapat digunakan dalam pembuatan hand sanitizer organik ini. Pembuatan hand sanitizer dari lidah buaya ini dilakukan dengan mencampurkan lidah buaya yang sudah di blender dengan alkohol hingga tercampur dengan rata,kemudian dilakukan pencampuran bahan lain seperti perasan jeruk nipis dengan tujuan untuk menambah keharuman hand sanitizer dan melembutkan tangan.Kemudian setelah semuanya tercampur dengan rata,cairan ini di diamkan selama 24 jam agar cairan yang sudah tercampur ini tidak terkontaminasi oleh bakteri yang ada didalam wadah. Dalam pembuatan hand sanitizer organik ini ada beberapa alat dan bahan yang dipelukan yaitu seperti: Alat yang digunakan pada kegiatan ini antara lain: Gelas ukur,Blender,Sendok pengaduk, Wadah kosong (untuk menyimpan cairan yang sudah jadi) Mangkuk bersih (untuk proses pencampuran bahan). Bahan yang digunakan 
pada kegiatan ini antara lain:

Lidah buaya,Alkohol,air perasan jeruk nipis (opsional) sesuai aroma yang disukai.

\section{Tahap pelaksanaan}

Adapun langkah-langkah dalam pembuatan hand sanitizer ini adalah sebagai berikut:

1. Pisahkan kulit luar lidah buaya,dan ambil pelepahnya,

2. Cuci pelepah lidah buaya dengan air mengalir sebelum dihancurkan menggunakan blender yang bersih hingga benar-benar halus,

3. Siapkan alkohol $96 \%$ dan ukur menggunakan gelas ukur sebanyak 300ml,lalu tuang ke wadah yang sudah disapkan untuk menyimpan cairan antiseptiknya,

4. Campurkan lidah buaya yang sudah di blender/dihaluskan sebanyak 100ml,lalu aduk menggunakan sendok pengaduk sampai merata,
5. Lalu tambahkan 10 tetes air perasan jeruk nipis dan aduk hingga merata,

6. Kemudian setelah semuanya tercampur dengan rata,cairan ini didiamkan selama 24 jam agar cairan yang sudah tercampur tidak terkontaminasi oleh bakteri yang ada didalam wadah,

7. Setelah seharian didiamkan, hand sanitizer bisa digunakan/dipakai.

\section{HASIL DAN PEMBAHASAN}

Hasil pembuatan lidah buaya sebagai antiseptik pembersih tangan adalah kadar alkohol yang dihasilkan menjadi $70,2 \%$ dan itu sudah efektif untuk membunuh kuman, bakteri, virus,dan aman untuk kulit.Kegiatan ini bertujuan untuk meningkatkan pemahaman/ pengetahuan tentang banyaknya manfaat yang dikandung lidah buaya dan buah jeruk nipis sebagai salah satu kekayaan alam Indonesia. Kegiatan ini diawali dengan penyuluhan tentang manfaat 
dan kandungan hand sanitizer berbahan dasar lidah buaya. Hal ini bertujuan agar masyarakat dapat mengetahui betapa banyak manfaat menggunakan hand sanitizer lidah buaya dan buah jeruk nipis yang bahan-bahannya bisa didapat disekitar lingkungan, bahkan dapat ditemui dalam kehidupan sehari-hari. Lidah buaya mempunyai sifat antiinflamasi dan anti-bakteri, sehingga cocok untuk digunakan sebagai bahan pembersih permukaan kulit, seperti hand sanitizer. Senyawa dalam lidah buaya tidak hanya bisa membersihkan tangan dari bakteri dan virus, namun juga bisa membuat tangan jadi lebih lembab.

Sedangkan beberapa penelitian yang telah dilakukan membuktikan air perasan jeruk nipis yaitu staphylococcus aureus, streptococcus mutans, salmonella thyposa. Jeruk nipis mengandung unsur-unsur senyawa kimia yang bermanfaat misalnya limonene, linalin asetat, fellandren dan sitral. Sari jeruk nipis dimanfaatkan di dalam industri kosmetik sebagai bahan untuk memperkecil pori-pori wajah, membersihkan dan menyegarkan. Dengan begitu, hand sanitizer dari lidah buaya akan relatif lebih aman jika dibandingkan dengan hand sanitizer pada umumnya yang didominasi bahan kimia. Dalam kegiatan inipula diharapkan dapat meningkatan keterampilan melalui pelatihan pembuatan hand sanitizer dari lidah buaya dan sari buah jeruk nipis dengan metode sederhana dan biaya yang relatif terjangkau.Kunci untuk membuat cairan pencuci tangan berbasis alkohol ini efektif membunuh kuman adalah dengan mempertahankan perbandingan alkohol 3:1 dengan lidah buaya. Produk-produk hand sanitizer ini telah memberikan kenyamanan dibandingkan dengan mencuci tangan menggunakan sabun dan air mengalir atau ketika wastafel cuci tangan sulit dilakukan. 
Perbandingan ini sudah banyak disarankan oleh beberapa dokter maupun professor seperti professor Jagdish Khubchandani,PhD. Beliau adalah profesor ilmu kesehatan di Ball State University. Respon masyarakat terhadap kegiatan ini sangat antusias mengingat hand sanitizer sering digunakan dalam keseharian peserta baik di rumah ataupun menjadi teman saat perjalanan. Banyak penduduk sekitar, khususnya yang mengalami ekonomi rendah awalnya tidak pernah membawa dan bahkan tidak pernah membeli produk hand sanitizer apapun di pasaran,lantaran harganya yang sangat tinggi.Sejak berlangsungnya kegiatan ini masyarakat dilingkungan sekitar merasa terbantu dan sering membawa hand sanitizer organic ini kemana pun mereka pergi.Mereka selalu membawa hand sanitizer ini dengan ukuran yang kecil sehingga mudah untuk dibawa kemana-mana. Kegiatan ini dapat memberikan solusi pembuatan sediaan untuk kesehatan pribadi dengan harga yang sangat terjangkau dan bahan yang mudah didapat, serta memiliki nilai ekonomis yang tinggi, karena setelah diolah bahan-bahan ini dapat menghasilkan suatu produk yang memiliki nilai jual yang cukup tinggi. Bahkan ada seorang mahasiswa di lingkungan ini mulai membuat sendiri dan memasarkan kepada temantemannya dengan harga yang ekonomis yaitu satu botol hand sanitizer ukuran 60ml harganya adalah Rp25.000.

\section{SIMPULAN}

Masyarakat bisa lebih antisipasi dalam menghadapi virus ini dan tetap menjaga kebersihan dimanapun mereka berada. Selain itu kegiatan ini diharapkan mampu menjadi gambaran atau terobosan baru bagi para mahasiswa atau kaum muda untuk dapat meningkatkan pendapatan dimasa pandemic seperti 
sekarang ini,juga kedepannya lebih memanfaatkan bahan-bahan alami. Melihat pemanfaatan lidah buaya dilingkungan ini masih sangat minim dan belum bervariasi,disinilah ada peluang jika bahan ini diolah lebih bermanfaat. Adanya budi daya lidah buaya di desa ini dapat dimanfaatkan dan diolah menjadi antiseptik yang dapat bermanfaat untuk masyarakat,dengan potensi yang ada menjadi lebih bermanfaat dan memberi nilai tambah bagi kehidupan masyatakat. Dengan begitu peningkatan kualitas hasil olahan ini dapat dikatakan sangat membantu. Capaian secara jangka pendek dari kegiatan pengabdian ini adalah dapat membantu meningkatkan kesadaran serta mempertahankan ekonomi masyarakat desa Renon.

\section{UCAPAN TERIMA KASIH}

Penulis mengucapkan terima kasih kepada Dosen pembimbing Komang Sri Widiantari,S.E.,M.S.i atas bimbingan selama kegiatan dan juga terima kasih banyak kepada warga Tukad Badung 18, desa Renon, Denpasar selatan atas kerjasama dan kontribusinya terhadap kelancaran kegiatan pengabdian masyarakat kali ini.

\section{REFERENSI}

https://jurnal.umj.ac.id/index.p hp/jurtek/article/download/4882/39 $\underline{04}$.

https://media.neliti.com/media/publ ications/189002-ID-pemanfaataninfusa-lidah-buaya-aloe-vera.pdf https://repository.ung.ac.id/skripsi/s how/821314004/formulasi-sediaan$\underline{\text { hand-sanitizer-ekstrak-lidah-buaya- }}$ aloe-vera-sinensis-dan-uji-aktivitasantibakterinya-terhadap-bakteri$\underline{\text { staphylococcus-aureus.html }}$ 